\title{
ASSESSING THE KNOWLEDGE OF DIETITIANS REGARDING DIET AND ORAL HEALTH IN BANGALORE, INDIA
}

\author{
Shwetha Hulikere Lingaraj ${ }^{1}$, Padma Keshav Bhat ${ }^{1}$ and Aruna C.N² \\ ${ }^{1}$ Department of Public Health Dentistry, Raja Rajeswari Dental College And Hospital, Bangalore, India Department of Public \\ ${ }^{2}$ Health Dentistry, Vydehi Institute Of Dental Sciences, Bangalore, India
}

\section{ARTICLE INFORMATION:}

\section{Article History:}

Received: 19 November, 2013

Accepted in revised form: 16 May,

2014

Published:1 August, 2015

Corresponding author:

Shwetha Hulikere Lingaraj

E-mail: searchdrshwetha@gmail.com

\section{Keyword:}

Dietitian, diet, oral health, knowledge.

\section{ABSTRACT:}

Background: Diet and oral health have a synergistic bidirectional relationship. As a body of knowledge, dietetics, and nutrition has expanded to touch all segments of health care. Collaboration between dietetics and dental professionals is recommended for oral health promotion and disease prevention and intervention.

Aim: To assess the knowledge of dietitians regarding diet and oral health in Bangalore, India. Material and Methods: A cross-sectional study was conducted. A close ended, self-administered 23 item questionnaire was distributed and collected after ten minutes. The data was subjected to statistical analysis. Settings: Different sectors like multi-specialty hospitals, private clinics, educational institutions. Subjects: All the life members of Indian Dietetic Association, Bangalore chapter.

Results: $36 \%$ felt dietary supplements can prevent oral mucosal diseases and only $12 \%$ were aware that high content of fluoride in water leads to abnormal tooth defects. Overall knowledge of dietitians pertaining diet and oral health was $56.48 \%$.

Conclusion: Study highlights the deficiency of knowledge of dietitians regarding oral health. The multifaceted interactions between diet and oral health in practice, education and research in both dietetics and dentistry merit detailed delineation.

الملخص العربي

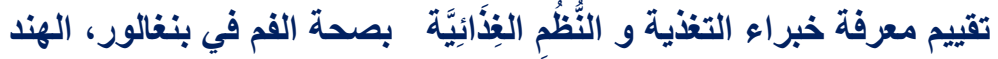

$$
\begin{aligned}
& \text { شويتا لينقر اج 1،بادما بات } 1 \text { ، أرونا سي أن2 }
\end{aligned}
$$

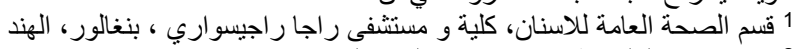

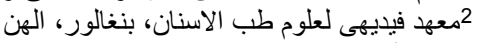

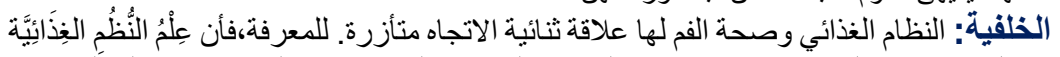

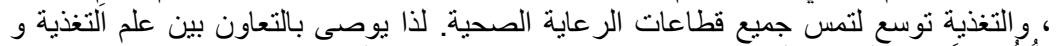

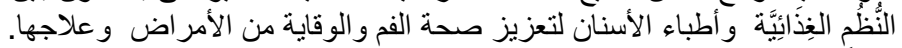

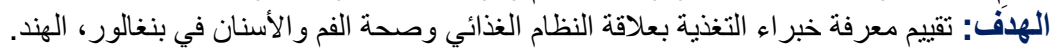

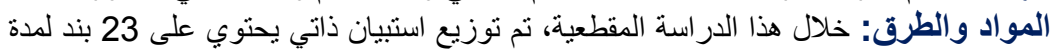

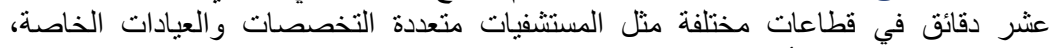

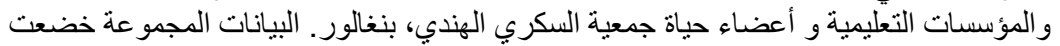
إلى التحليل الإحصائي. النتائج: ور أى 36٪ من الإحشاركين أن المكملات الغذائية وقاية من الأمراض المخاطية الفموية

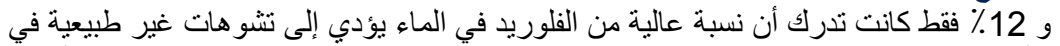

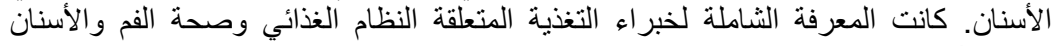

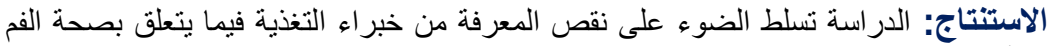

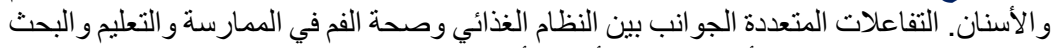
في كل علم التغذية وطب الأسنان تستحق أهتمام أكثر تفصيلا. 


\section{INTRODUCTION:}

Unique oral cavity- a gatekeeper to diet and is often referred to as mirror of overall health ${ }^{1}$. The oral cavity is the pathway to the rest of the body, so any problems in the oral cavity can profoundly affect appetite and ultimately diet. Diet may affect the development and integrity of the oral cavity as well as progression of oral diseases $^{2,3}$. Diet affects the teeth during development and malnutrition may exacerbate oral infectious diseases ${ }^{4,5}$. Diet and oral health have a synergistic bidirectional relationship. As a body of knowledge, dietetics, and nutrition has expanded to touch all segments of health care. Scientific and epidemiological data suggest a lifelong synergy between nutrition and the integrity of the oral cavity in health and disease. As we advance in our discoveries of the links between oral and nutrition health, practitioners of both disciplines must learn to provide screening, baseline education, and referral to each other as part of comprehensive client/patient care $^{6,7,8}$. Thus, partnerships among dietetics, dental, and other health professionals need to be identified, developed, strengthened, and expanded to encourage integrated, comprehensive practice. The multifaceted interactions between nutrition and oral health in practice, education, and research in both dietetics and dentistry merit detailed delineation. Collaboration between dietetics and dental professionals is recommended for oral health promotion and disease prevention and intervention. Paralleling this cross-disciplinary trend is a change in the health care system towards a coordinated team care approach that requires collaborative effort among health care providers. Hence, the study was undertaken.

\section{MATERIALS AND METHODS:}

A cross-sectional study was conducted among dietitians of Bangalore city. All the life members of Indian Dietetic Association, Bangalore chapter, India were included in the sample. The list of life members of Indian Dietetic Association consisted a total of 339 dietitians. 43 of them were not accessible during the study period due to various reasons like out of station, health problem etc. Hence, the total of 296 were included in the study.

\section{Organization and Administration Workout:}

Approval from authorities: Permission to conduct the study was obtained from the Indian Dietetic
Association, Bengaluru chapter. Ethical clearance: The study was conducted according to the guidelines laid down in the declaration of Helsinki and all procedures involving human subjects/patients were approved by the name of the ethics committee removed for blinding. Informed consent: the purpose and details of the study was explained to the dietitians and written informed consent was then obtained from them. A close ended self - administered 23 item questionnaire with four multiple choices consisting of knowledge about diet and oral health like dietary sugars and its association with dental caries, dental history and oral health advice in dietary counseling, protective effect of fibrous food against dental caries, sugar substitutes, trace elements present in the diet, fluoride, abnormal tooth defects, vitamins and micronutrients for children, oral mucosal diseases with nutritional deficiencies gingival bleeding, tooth wear, nonmilk extrinsic sugars, dietary suggestions for infants, children and geriatrics, malnutrition and crowding of teeth, oral clearance of carbohydrates, dry mouth and dietary deficiencies, vitamin deficiencies and oral cancer, low birth weight and bleeding gums, teeth friendly foods, diet and oral health in diabetics, professional relation between dentist and dietetics was used. Questions designed were close ended so that the categories could be analyzed efficiently and with minimum bias. Study design attempted to minimize the limitation of self-administered questionnaires by: 1) Formulating questions using lay terms, 2) Spreading out questions so that they were uncluttered and broken down into different sections and 3) Attaching the cover page explaining the details of the study, giving instructions on completing the questionnaire. A Pilot study was conducted among 34 dietitians. Validity of questionnaire was assessed. Face validity was checked by asking experts to scrutinize the questions, while content validity was checked by ensuring that the questions covered all the areas of knowledge mapped out by initial objective. Cronbach's $\alpha$ obtained was 0.83 . Dietitians working in different sectors like multi-specialty hospitals, private clinics, and educational institutions were personally contacted and administered the questionnaire and was duly collected after 10 minutes. Results were subjected to statistical analysis. 


\section{Statistical analysis:}

Descriptive statistical analysis has been carried out in the present study. The Statistical software namely SPSS 13.0, were used for the analysis of the data and Microsoft word and Excel have been used to generate graphs and tables.

\section{RESULTS:}

The present study was conducted to evaluate the knowledge of dietitians regarding diet and oral health. A cross-sectional survey was conducted among dietitians, who were the life members of Indian Dietetic Association, Bengaluru Chapter, and Bengaluru. The average knowledge percentage obtained was $56.48 \%$. One third of dietitians opted selenium, $23 \%$ agreed for molybdenum, $13 \%$ felt fluoride and $31 \%$ thought vanadium as trace elements which has protective effect against dental caries (Fig a). More than one third $(39 \%)$ of the dietitians felt confectionaries among non-milk extrinsic sugars are the greatest threat to dental health of children and only $1 \%$ opted for fruit juices and $4 \%$ for honey and syrups and $55 \%$ were having correct knowledge about non milk extrinsic sugar and dental health (Fig b). $52 \%$ of dietitians opted carbonated and sport drinks, only $2 \%$ opted for citrus fruit, $0 \%$ for vitamin c chewable tablets, as the cause of tooth wear (Fig c). $16 \%$ of dietitians accepted, $41 \%$ denied, $28 \%$ were not sure and $15 \%$ were unaware that low birth weight of a child is associated with bleeding gums during pregnancy (Fig d). Nearly two thirds $(67 \%)$ of dietitians accepted, 3\% didn't accept, 30\% were not sure that dental history and oral health advice are important aspects in dietary counseling. Seventy percent answered appropriately that fluoride eliminate the sugar-caries relationship. $65 \%$ were sure, $27 \%$ opted for calcium and vitamin supplements, $7 \%$ opted for fibrous food and $0 \%$ opted for legumes and grains as dietary suggestions for geriatrics regarding oral health. $14 \%$ felt micronutrients, $23 \%$ thought antioxidants, $9 \%$ felt $\beta$ carotene, $54 \%$ had appropriate knowledge about protective effects against oral cancer. 93\% appropriately answered that after the intake of sweets or sweetened drinks, it is important to rinse the mouth with water. $41 \%$ were aware that food rich in protein and fat increases oral clearance of carbohydrates. $32 \%$ opted vitamin A and vitamin B6 deficiency, 12\% opted iron deficiency, 9\% opted essential fatty acid deficiency as the causes for dry mouth (Table 1).

\section{DISCUSSION:}

The changing social and economic realities of today's health care system have had a dramatic effect on the preparation and training of dietetics professionals. The core knowledge of principles of nutrition and diet and their clinical application in practice provides the underpinning for achievement of several of the competencies. A majority $(81 \%)$ of dietitians were aware that fibrous food has protective effect against dental caries. The main reason that fibrous foods protect the teeth is because they mechanically stimulate salivary flow.9-11 A study 12 conducted by $\mathrm{k}$ Shah found that only $4 \%$ of dietetic and nutrition students thought that consumption of dried fruit might lead to oral health problems but in the present study $11 \%$ dietitians felt dry fruits causes dental caries. Dried fruit may potentially be more cariogenic since the drying process breaks down the cellular structure of the fruit, releasing free sugars and dried fruits tend to have a longer oral clearance $^{12,13}$. About one quarter $(23 \%)$ opted antioxidants and 14\% opted micronutrients as protective measures against oral cancer. Micronutrient intakes via diet have been found to have an inverse relationship with incidence of oral cancer 14,15 . Sixteen percent of dietitians agreed low birth weight of a child is associated with bleeding gums during pregnancy. Newesearch suggests a link between preterm, low birth weight babies and gingivitis. Excessive bacteria, which cause gingivitis, can enter the bloodstream. If this happens. The bacteria can travel to the uterus, triggering the production of chemicals called "prostaglandins", which case uterine contractions that induce premature labor. The positive correlation between maternal gingival status and low birth weight was demonstrated by other authors ${ }^{16-18}$.One third (33\%) dietitians were aware trace element selenium present in the diet doesn't have protective effect against dental caries. The incorporation of trace element selenium into the apatite microcrystals of enamel may alter their physical properties and hence their susceptibility to degradation ${ }^{19}$. Seventy one of dietitians felt vitamin deficiencies and tobacco intake leads to increases risk of precancerous lesions. An important second aspect which needs to be considered is the pre-conditioning of the oral mucosa by a prolonged, chronic deficiency of iron and/or vitamin B complex ${ }^{20}$. 
Table 1: Distribution of dietitian's knowledge regarding diet and oral health.

\begin{tabular}{|c|c|c|c|}
\hline Qvestions & Response & Frequency & Percentage \\
\hline $\begin{array}{l}\text { Dental history and oral health advice } \\
\text { are important aspects in dietary } \\
\text { counseling. }\end{array}$ & $\begin{array}{l}\text { Yes } \\
\text { No } \\
\text { Maybe } \\
\text { Dont know }\end{array}$ & $\begin{array}{l}199 \\
9 \\
88\end{array}$ & $\begin{array}{l}67 \% \\
3 \% \\
30 \%\end{array}$ \\
\hline $\begin{array}{l}\text { Importance of rinsing movth with } \\
\text { water after the intake of sweet or } \\
\text { sweetened drinks }\end{array}$ & $\begin{array}{l}\text { Yes } \\
\text { No } \\
\text { Maybe } \\
\text { Dont know }\end{array}$ & $\begin{array}{l}275 \\
4 \\
17\end{array}$ & $\begin{array}{l}93 \% \\
1 \% \\
6 \%\end{array}$ \\
\hline $\begin{array}{l}\text { Fuoride eliminate the sugar-caries } \\
\text { relationship }\end{array}$ & $\begin{array}{l}\text { Yes } \\
\text { No } \\
\text { Maybe } \\
\text { Dont know }\end{array}$ & $\begin{array}{l}207 \\
19 \\
52\end{array}$ & $\begin{array}{l}70 \% \\
6 \% \\
18 \%\end{array}$ \\
\hline $\begin{array}{l}\text { Diet suggestions for geriarics } \\
\text { regarding oral health: }\end{array}$ & $\begin{array}{l}\text { Calciom and Vitamin sup. } \\
\text { Fibrous food } \\
\text { Legummes and grains } \\
\text { All of the above }\end{array}$ & $\begin{array}{l}81 \\
22 \\
1\end{array}$ & $\begin{array}{l}27 \% \\
7 \% \\
0 \%\end{array}$ \\
\hline $\begin{array}{l}\text { Protective effect agginst oral cancer is } \\
\text { povided by. }\end{array}$ & $\begin{array}{l}\text { Micronutrient } \\
\text { Anti-oxidants } \\
\text { Beta-carotene } \\
\text { All of the above }\end{array}$ & $\begin{array}{l}40 \\
69 \\
27 \\
160\end{array}$ & $\begin{array}{l}14 \% 6 \\
23 \% \\
9 \% 6 \\
54 \%\end{array}$ \\
\hline $\begin{array}{l}\text { Food rich in protein andfat increases oral } \\
\text { claarance of catbolydrats }\end{array}$ & $\begin{array}{l}\text { Yes } \\
\text { No } \\
\text { Maybe } \\
\text { Don't lnow }\end{array}$ & $\begin{array}{l}122 \\
77 \\
60 \\
37\end{array}$ & $\begin{array}{l}41 \% 6 \\
26 \% 6 \\
20 \% 6 \\
13 \%\end{array}$ \\
\hline Dry Mouth occurs in: & $\begin{array}{l}\text { VitA and Vit b } 6 \text { deficiency } \\
\text { Iron deficiency } \\
\text { Essential FA deficiency } \\
\text { All of the above }\end{array}$ & $\begin{array}{l}95 \\
36 \\
27 \\
138\end{array}$ & $\begin{array}{l}32 \% \\
1296 \\
996 \\
47 \% 6\end{array}$ \\
\hline
\end{tabular}

More than one third $39 \%$ of dietitians felt malnutrition leads to crowding of teeth. In the field of oral health, the association between malnutrition and impaired growth and the development of facial bones has been reported by a number of researchers and has been linked to a reduction in the length of the skull base and jaw height. It is believed therefore that malnutrition may also be associated with malocclusion, particularly dental crowding, which is defined as misalignment of the teeth due to insufficient space for them to erupt in the correct place ${ }^{21}$. Dietitians need to develop the skills required to interpret, translate and apply nutritional science to provide practical, impartial and safe information about diet and oral health. In this context, dietitians should be able to provide frontline consultations for individuals and groups as well as training and supporting other members of the health care team to provide informed, realistic and practical dietary advice.

\section{CONCLUSION:}

Consistent with the current climate of health care delivery, which stresses collaboration between health care providers, qualified dietetics and dental professionals should pursue opportunities to create a health care paradigm that will mesh optimum oral and nutrition health care with improved oral, nutritional, and systemic health status. To prepare practitioners with the skills and knowledge that exemplifies this paradigm in practice, dietetics and dental educators must assume responsibility for integrating oral health/ diet and nutrition topics and clinical/community experiences in education, respectively. As a body of knowledge, dietetics, and nutrition has expanded to touch all the segments of health care. Multi skilling on basic levels of care, including risk identification and referral for intervention, will foster successful strategies related to oral health and diet.

\section{REFERENCES:}

1) Position of The American Dietetic Association: Oral health and nutrition. J Am Diet Assoc. 1996;103:615-625.

2) Pew Health Professions Commission. The Fourth Report of the Pew Health Professions Commission. San Francisco, CA: Center for the Health Professions; December 1998.

3) US Department of Health and Human Services. Oral Health in America: A Report of the Surgeon General. Executive Summary. Rockville, MD: US Dept of Health and Human Services, National Institute of Dental and Craniofacial Research, National Institutes of Health; 2000.

4) Konig KG. Diet and oral health. Int Dent J. 2000;50:162-174.

5) Hargreaves JA. Discussion: Diet and nutrition in dental health and disease. Am J Clin Nutr. 1995;61(suppl):447S-448S.

6) Position of The American Dietetic Association: Nutrition services for children with special health care needs. J Am Diet Assoc. 1995;95:809-812.

7) Position of The American Dietetic Association: Oral health and nutrition. J Am Diet Assoc. 2003;108:713-730

8) Position of The American Dietetic Association: Oral health and nutrition. J Am Diet Assoc. 2007;98:676-690.

9) Sheiham A. Dietary effects on dental diseases. Public Health Nutrition 2001; 4: 569-91.

10) Moynihan PJ, Snow S, Jepson NJA, Butler TJ. Intake of non- starch polysaccharide (dietary fiber) in edentulous and dentate persons: an observational study. British Dental Journal 1994; 177: 243-7.

11) Joshipura KJ, Willett WE, Douglass CW. The impact of edentulousness on food and nutrient intake. Journal of the American Dental Association 1966; 129: 1261-9.

12) Shah K, M.L. Hunter, R.M. Fairchild. A comparison of the nutritional knowledge of dental, dietetic and nutrition 
students.British Dental Journal 2011; 210: $33-38$

13) Moynihan P J. Dietary advice in dental practice.British Dental Journal 2002; 193:563-568

14) Jennifer $M$ MacKeown.Energy and macronutrient intake in relation to dental caries incidence in urban black South African preschool children in 1991 and 1995: the Birth-to-Ten study.Public health nutrition:3(3), 313-319

15) Paula Moynihan.Diet, nutrition and the prevention of dental diseases.Public health nutrition:7(1A),201-226

16) Offenbacher, S, Katz, V, Gertik, G, Collins, J., Boyd, D, Maynor, G. \& Mackaig, R.M. periodontal infection as a possible risk factor for preterm low birth weight. Journal of Periodontology 1996; 67: 1103-13.

17) Dasanayake, AP Boyed, D. Madianos, $P$. N. Offenbacher, S. \& Hills, E. The association between Prophyromonas gingivalis - specific maternal serum IgG and low birth weight. Journal of periodontology 2001; 72, 1491-97.
Shwetha Hulikere Lingaraj et al.

18) Jeffcoat, M. K. Gerus, N. C. Reddy, M. S. Liver, S. P. Goldenberg, R. L. \& Hauth, J. C. periodontal infection and preterm birth. Results of a prospective study. Journal of the Amercian Dental Association 2001; 132: 875-80.

19) Davies BE, Anderson RJ. The epidemiology of dental caries in relation to environmental trace elements. Experientia. 1987 Jan 15;43(1):87-92

20) Teresa a. marshall, John j. warren, Jed s. hand et al.Oral health, nutrient intake and dietary quality in the very old.J Am Dent Assoc, Vol 133, No 10, 1369-1379.

21) Erika B. A. F. Thomaz,Maria Cristina T. Cangussu, Antônio Augusto M. da Silva et al.Is malnutrition associated with crowding in permanent dentition.Int $\mathbf{J}$ Environ Res Public Health. 2010 September; 7(9): 3531-3544. 